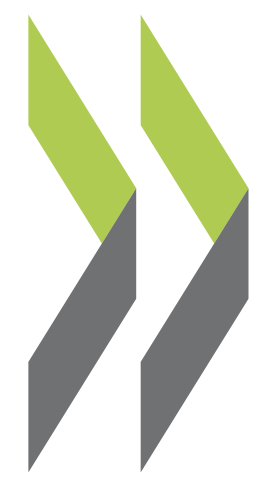

PEB Exchange, Programme on Educational Building 1998/10

\title{
A Visit to Three Parisian School Libraries
}

\section{Jill Gaston}




\section{A VISIT TO THREE PARISIAN SCHOOL LIBRARIES}

An architect and a librarian from the Albania Educational Development Program were in Paris for the PEB Experts' Meeting on Libraries and Resource Centres for Tertiary Education. While in town, they visited three public schools - an elementary school, a middle school, and a high school - for ideas on the planning and use of libraries based on French examples. This brief report of their tour illustrates contemporary practice.

\section{Lycée TeChn ologique RAsPail}

This technical high school, a new construction on the edge of Paris, opened in January 1996. The school is made up of three parallel, rectangular buildings of three floors each, connected by glass passage ways. Its resource centre, or CD I (Centre de documentation et d'information), is located in the heart of the school, in the centre of the middle building.

The CDI is equipped with five computers for student and teacher use and one for library management, two printers and eight very popular CD-ROM readers.

The librarian, or documentaliste, was responsible for organising the use of the $340 \mathrm{~m}^{2}$ space and purchasing the necessary furniture, planning for ten years' growth. Flexibility is ensured in part by the use of different types of tables - square, round and quadrangular ones which can be pushed together into various combinations. O ne corner of the CDI has sound-insulated hanging partitions to create a separate room for the librarian or a teacher to hold class.

The "cultural corner" resembles a den, with low stuffed chairs around a coffee table. Beneath a wall of windows, the latest issues of the resource centre's 90 periodical subscriptions are displayed on shelves housing the past year's issues. Another wall is reserved for information on cultural activities. Storage rooms on two corners of the resource centre hold archived periodicals and audio-visual material which is loaned to classes.

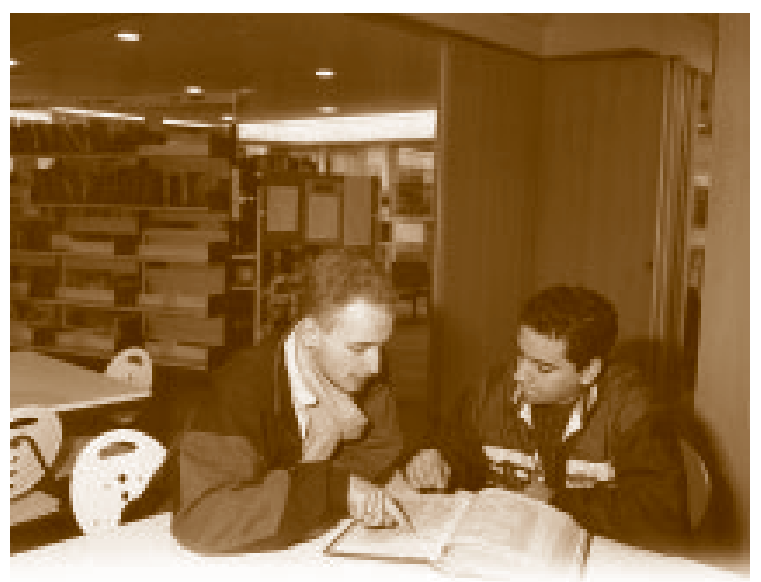

At the beginning of the school year the librarian gives all students a 90-minute initiation into using the resource centre, including how to use an encyclopaedia and an explanation of the classification system. She said that once they have learned to do research using the system there, they will have the tools they need to be able to use university libraries.

The CDI is open to students and staff throughout the school day till 5:30 p.m.

The school was designed to be robust and able to withstand heavy use and occasional misuse while retaining consideration for comfort and aesthetics. Eight terraces with benches are interspersed around the school. The hallways have anti-graffiti paint on the top half of the walls, and the bottom halves have a rubber-like coating that can be swept or mopped. Doors are of a high-quality to withstand kicking. In the halls are drink machines, and nearby are television monitors suspended from the ceiling, used for announcements. The lunchroom's elegant wooden chairs with carved backs reflect a sense that the students are worth pleasing.

A presentation of the school is included in the 50-page bulletin about the $C D I$ that the librarian updates annually. It provides details of the layout, services and rules of the resource centre.

\section{Collège A ndré Citroën}

The Collège André Citroën is a middle school which was built in 1989, also on the periphery of Paris. Its resource centre is tucked away at the end of a mezzanine above the school's spacious, glassed-in entrance, opposite the administrative offices. 

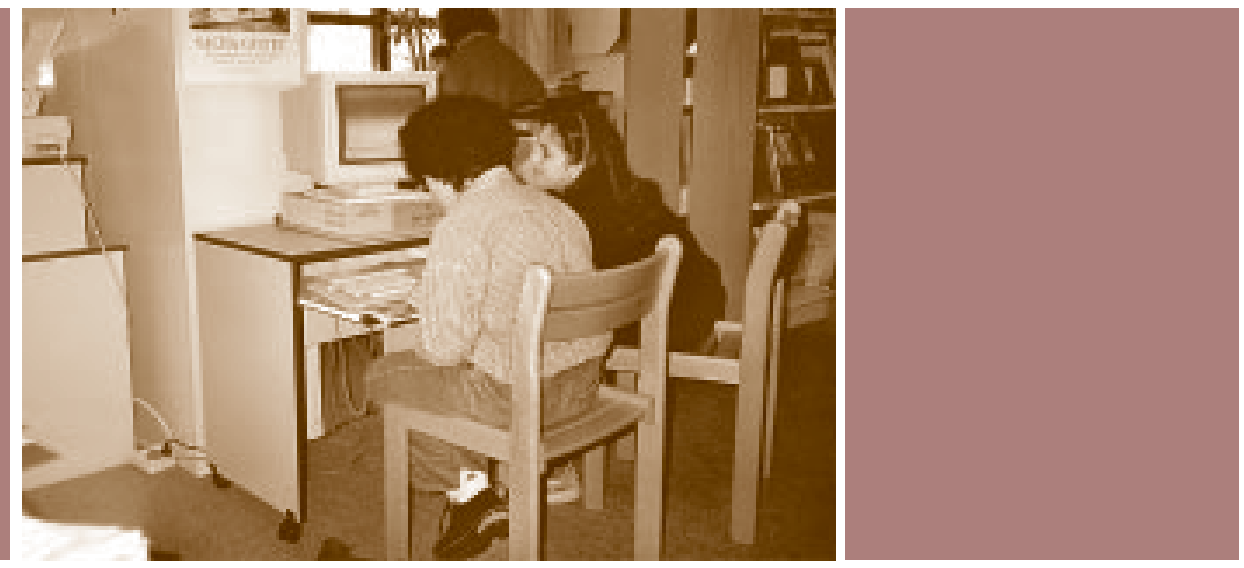

Like the other two schools visited, the CDI uses a combination of the Dewey system and colour coding to classify its books. Four computer terminals give access to the electronic catalogue and are available to students for word processing; they share one printer. There are plans to network with other schools once their own system is completely functional.

Tables and rows of shelves are interspersed, allowing students to work amongst the books. A central shelf is reserved for new acquisitions which students check out immediately, and their titles are posted in the teachers' lounge. A municipal library nearby brings books for loan every two weeks on a different theme; at the time of the visit it was science fiction. The resource centre has its own budget as does each teacher; materials they buy are generally kept in their classrooms.

The documentaliste underlined the importance of working closely with teachers and cited successful examples. The French teacher contacted her before assigning a research project on the Louvre museum; she was able to order in advance the books the students would need that were not already on hand.

For the history teacher's lessons on children's rights, the librarian contacted UNICEF, which complemented the classroom work with speakers and materials. Together the students wrote a text on the subject. A second teacher was then included in the project: the text was given to the computer teacher for his students to work on presentation, making a booklet for distribution. The librarian would like to pursue exploiting the resource centre's capacity as a link between teachers.

\section{ECOLE ÉLÉMENTAIRE}

The third visit was to a 100-year-old elementary school, at O deon in the heart of Paris, with only sixclasses and 140 pupils.

Their library is the result of eight years' work by the parents' association, and a classroom was sacrificed to make space for it. The State does not provide a budget for libraries in elementary schools, so parents raised the funds for renovation and collected the books. The G overnment now donates about 50 books a year and pays the librarian's salary. She sees as her role to teach the children that books are not just for studying but are fun, and to judge by the fact that they compete over who gets to spend recreation time in the library, she has been successful.

A small computer room next door is used for word processing by all grades, including the first graders after spending four or five months learning to read. The school's two largest rooms are first grade classrooms; the principal explained that the smallest children need the most space.

Touring the rest of the building, our visitors were impressed by the restrooms adapted to the small users. Above the child-level sinks, a glass wall permits surveillance from a distance. The joints of the stall doors are covered with expandable rubber strips to prevent fingers from getting pinched.

This visit ended, as had the others, with the Albanian visitors remarking the willingness of the librarians and administrators to open the doors of their schools and share the experience and the information they had to offer. The PEB Secretariat would like to thank them.

For further information, contact the PEB Secretariat: Tel.: 33 (0)1 452494 62, Fax: 33 (0)1 422402 11, E-mail: jill.gaston@oecd.org. 